\title{
ASUPAN PROTEIN, ZAT BESI DAN STATUS GIZI PADA REMAJA PUTRI
}

\author{
Martha Pitaloka Putri ${ }^{1}$, Dary $^{2}$, Gelora Mangalik ${ }^{1 *}$ \\ ${ }^{1}$ Program Studi Gizi, Fakultas Kedokteran dan Ilmu Kesehatan, Universitas Kristen Satya Wacana \\ Jl. Kartini No.11A, Sidorejo Lor, Kec. Sidorejo, Kota Salatiga, Jawa Tengah 50714, Indonesia \\ ${ }^{2}$ Program Studi Ilmu Keperawatan, Fakultas Kedokteran dan Ilmu Kesehatan, Universitas Kristen Satya Wacana \\ J1. Kartini No.11A, Sidorejo Lor, Kec. Sidorejo, Kota Salatiga, Jawa Tengah 50714, Indonesia \\ *Korespondensi : E-mail: gelora.mangalik@uksw.edu
}

\begin{abstract}
Background: Iron and protein intake plays an important role for growth in adolescence. Unbalanced nutrient intake can lead to nutritional problems such as underweight or overweight in adolescents.

Objectives: The aims of this study was to examine the relationship between protein, iron, and nutritional status in adolescent girls.

Methods: This research was conducted in November 2020 - January 2021 with a cross-sectional research design. 88 female students aged 15-18 years at SMAN 1 Kendal were selected by simple random sampling. Data collection was carried out by measuring body weight using digital scales and height using a microtoise. Protein and iron intake were obtained by using the SQ-FFQ method and food record $2 \times 24$ hour then calculated using nutrisurvey software. Data analysis using bivariate analysis with the Spearman correlation test.

Results: The results this study showed protein intake with nutritional status $(p=0.848$ and $r=0.021)$ and iron intake with nutritional status ( $p=0.685, r=0.044)$. Most of the students had normal nutritional status $(84.09 \%)$, the adequacy level of protein was categorized as excessive (42.05\%), and iron adequacy level classified as deficit (54.55\%).

Conclusion: There is no relationship between protein intake with nutritional status and iron intake with nutritional status.
\end{abstract}

Keywords: Nutrients intake; Protein; Adolescents girl; Nutritional status; Iron

\begin{abstract}
ABSTRAK
Latar belakang: Asupan zat besi dan protein berperan penting untuk pertumbuhan pada masa remaja. Asupan zat gizi yang tidak seimbang dapat mengakibatkan masalah gizi seperti status gizi kurang atau lebih pada remaja.

Tujuan: Penelitian ini bertujuan untuk meneliti hubungan asupan protein, zat besi, dan status gizi pada remaja putri Metode: Penelitian ini dilaksanakan pada bulan November 2020-Januari 2021 dengan desain penelitian cross-sectional. Sampel yang digunakan adalah 88 siswi berusia 15-18 tahun di SMAN 1 Kendal yang dipilih secara simple random sampling. Pengumpulan data dilakukan melalui pengukuran berat badan dengan menggunakan timbangan injak digital dan tinggi badan menggunakan microtoise. Asupan protein dan zat besi diperoleh dengan metode SQ-FFQ dan Food Record $2 \times 24$ jam, kemudian dihitung dengan menggunakan software nutrisurvey. Analisis data penelitian menggunakan analisis bivariat dengan uji korelasi Spearman.

Hasil: Hasil uji korelasi Spearman menunjukkan asupan protein dengan status gizi ( $\mathrm{p}=0,848$ dan $\mathrm{r}=0,021)$ dan asupan zat besi dengan status gizi $(\mathrm{p}=0,685, \mathrm{r}=0,044)$. Sebagian besar siswi memiliki status gizi normal $(84,09 \%)$, tingkat kecukupan protein berlebih $(42,05 \%)$, dan tingkat kecukupan zat besi defisit $(54,55 \%)$.

Simpulan: Tidak terdapat hubungan antara asupan protein dengan status gizi dan asupan zat besi dengan status gizi.
\end{abstract}

Kata Kunci: Asupan zat gizi; Protein; Remaja putri; Status gizi; Zat besi

\section{PENDAHULUAN}

Status gizi adalah hasil akhir dari keseimbangan antara asupan makanan dan kebutuhan zat gizi dalam tubuh. ${ }^{1}$ Status gizi dibedakan menjadi tiga yaitu status gizi kurang, normal, dan berlebih. Secara global, prevalensi underweight (berat badan kurang) pada remaja adalah $8,4 \%$ untuk perempuan dan $12,4 \%$ pada laki-laki. ${ }^{2}$ Pada tahun 2016, rata-rata estimasi Indeks Massa Tubuh (IMT) untuk remaja berusia 10-19 tahun di Asia Tenggara adalah $<20$ untuk remaja pria dan wanita. ${ }^{2}$ Di Indonesia, prevalensi kurus pada remaja usia 13-15 tahun sebesar $11,1 \%$ dan prevalensi gemuk sebesar 10,8\%. Pada remaja usia 16-18 tahun, prevalensi kurus sebesar 9,4\% dan prevalensi gemuk sebesar 7,3\%. ${ }^{3}$ Berdasarkan hasil pemantauan status gizi di Provinsi Jawa Tengah, prevalensi status gizi sangat kurang pada remaja putri usia $12-18$ tahun sebesar $0,4 \%$, 
status gizi kurang sebesar 2,7\%, status gizi normal sebesar $73,4 \%$, status gizi lebih sebesar $17,5 \%$, dan obesitas sebesar $5,9 \%{ }^{4}$

Remaja merupakan salah satu kelompok rentan mengalami masalah gizi seperti gizi kurang maupun berlebih. Masalah gizi pada remaja perlu mendapatkan perhatian khusus, karena berpengaruh terhadap pertumbuhan yang akan berdampak di masa dewasa. ${ }^{5}$ Masa remaja dapat dikatakan sebagai kesempatan kedua untuk mengejar pertumbuhan apabila mengalami defisit zat gizi di awal kehidupan. Pada fase ini laju pertumbuhan terjadi dengan cepat, karena remaja merupakan transisi dari masa anakanak ke dewasa. Oleh karena itu, remaja putri membutuhkan zat gizi yang adekuat dari segi kuantitas dan kualitas untuk mengatasi pertumbuhan yang cepat dan risiko kesehatan lainnya yang meningkatkan kebutuhan gizi. ${ }^{6}$ Remaja harus memenuhi kebutuhan asupan energi, zat gizi mikro seperti protein dan zat gizi mikro seperti zat besi untuk dapat mencapai status gizi yang optimal.

Protein merupakan zat gizi yang sangat penting bagi tubuh, karena berfungsi sebagai sumber energi, zat pembangun dan pengatur. ${ }^{7}$ Kebutuhan protein untuk remaja perempuan usia 14-18 tahun adalah 0,85 gram $/ \mathrm{kgBB} / \mathrm{hari}^{8}{ }^{8}$ Proporsi asupan protein nabati adalah $60-80 \%$ kebutuhan protein dan protein hewani sebesar $20-40 \%$ kebutuhan protein. ${ }^{9}$ Tubuh manusia tidak dapat menyimpan protein secara berlebih, apabila asupan protein berlebih maka akan disimpan tubuh dalam bentuk trigliserida. Hal ini mengakibatkan jaringan lemak mengalami kenaikan, sehingga menyebabkan terjadinya status gizi lebih. ${ }^{10}$

Remaja putri yang mengalami kekurangan asupan protein dapat menyebabkan terjadinya Kurang Energi Kronis (KEK). KEK biasanya terjadi pada Wanita Usia Subur (WUS) berusia 15-45 tahun yang disebabkan karena kurang asupan energi dan protein yang berlangsung lama. ${ }^{11}$ Seseorang yang KEK dapat mengalami penurunan berat badan, karena rendahnya simpanan energi dalam tubuh. Pada tahun 2013, prevalensi underweight pada remaja usia 16 - 18 tahun sebesar 9,4\% (1,9\% sangat kurus dan 7,5\% kurus) dan mengalami kenaikan pada 2018 sebesar 36,3\% terjadi pada WUS tidak hamil yang dialami oleh remaja usia $15-19$ tahun. $^{12}$ Prevalensi KEK pada WUS usia 15 - 19 tahun di Provinsi Jawa Tengah pada tahun 2018 sebesar $42,53 \%{ }^{13}$

Sebagai hasil dari pertumbuhan intensif dan perkembangan otot, kebutuhan zat besi pada remaja mengalami peningkatan sehingga sangat penting untuk memenuhi kebutuhan zat besi pada remaja. ${ }^{14}$ Zat besi $(\mathrm{Fe})$ berperan dalam sintesis monoamina, metabolisme energi, mielinisasi, sistem neurotransmitter, dan metabolisme dopamin. ${ }^{15}$ Hubungan terbalik antara IMT yang tinggi dikaitkan dengan penyerapan $\mathrm{Fe}$ fraksional yang lebih rendah pada wanita usia subur, terlepas dari status Fe. ${ }^{16}$ Pada penelitian yang dilakukan oleh Ernyasih (2019) menunjukkan bahwa terdapat hubungan antara kebiasaan konsumsi sumber zat heme dengan status gizi $(\mathrm{p}=0.016) .{ }^{17}$ Zat besi heme dapat memengaruhi status gizi, karena zat besi heme berasal dari bahan makanan hewani sehingga mempunyai tingkat absorpsi $20-30 \%$ dan besi heme lebih mudah diserap oleh tubuh serta penyerapannya tidak tergantung dengan zat makanan lainnya. ${ }^{17}$

Defisiensi $\mathrm{Fe}$ dapat menurunkan fungsi kekebalan tubuh, apabila hal tersebut terjadi dalam jangka waktu yang lama maka akan mengakibatkan resistensi terhadap penyakit infeksi sehingga akan memengaruhi status gizi. ${ }^{18}$ Kurangnya asupan makanan dan pola makan yang buruk pada remaja putri seperti lebih memilih makanan cepat saji yang mengandung tinggi energi, lemak dan kandungan natrium, serta rendah vitamin, kalsium dan zat besi dapat menyebabkan terjadinya malnutrisi pada remaja. ${ }^{19}$ Berdasarkan latarbelakang diatas, peneliti tertarik untuk meneliti hubungan asupan protein, zat besi, dan status gizi pada remaja putri di SMAN 1 Kendal, Kecamatan Patebon, Kabupaten Kendal, Jawa Tengah.

\section{METODE}

Penelitian ini dilakukan di SMA Negeri 1 Kendal, Kecamatan Patebon, Kabupaten Kendal, Jawa Tengah pada bulan November 2020 - Januari 2021 dengan desain cross sectional. Jumlah sampel penelitian ini sebanyak 88 orang yang dipilih secara simple random sampling yakni siswi SMA Negeri 1 Kendal yang memenuhi kriteria inklusi dan eksklusi. Kriteria inklusi penelitian ini adalah siswi yang berusia 15-18 tahun, tidak sedang berpuasa, tidak memiliki penyakit infeksi dan bersedia menjadi subjek penelitian, sedangkan kriteria eksklusi pada penelitian ini adalah siswi yang tidak hadir saat penelitian berlangsung, sedang sakit, dan mengundurkan diri dari penelitian.

Pada penelitian ini, variabel dependen adalah status gizi pada remaja putri, sedangkan variabel independen adalah asupan protein dan zat besi. Jenis data yang digunakan adalah data primer yang dikumpulkan melalui wawancara, kuisioner, identitas subjek, data pengukuran secara langsung. Data primer terdiri atas karakteristik individu (jenis kelamin dan usia), data asupan makan (dietary), dan data antropometri (berat badan, tinggi badan).

Pengumpulan data penelitian dilakukan melalui pengukuran berat badan dengan menggunakan timbangan injak digital. Pengukuran 
tinggi badan menggunakan microtoise dengan ketelitian $0,1 \mathrm{~cm}$. Status gizi remaja putri ditentukan dengan menghitung nilai z-score indeks IMT/U menurut Kementrian Kesehatan Republik Indonesia (2020). ${ }^{20}$ Indeks massa tubuh menurut usia (IMT/U) pada anak usia 5-18 tahun yaitu gizi buruk (severely thinness) dengan $\mathrm{z}$-score $<-3 \mathrm{SD}$, gizi kurang (thinness) dengan z-score -3SD sampai dengan $<-$ 2SD, gizi normal dengan $\mathrm{Z}$-score -2SD sampai dengan $+1 \mathrm{SD}$, gizi lebih (overweight) dengan z-score $+1 \mathrm{SD}$ sampai dengan $+2 \mathrm{SD}$, dan obesitas (obese) dengan Z-score $>+2 \mathrm{SD}^{20}$

Data dietary diukur dengan metode Semi Quantitative Food Frequency Questionnaire (SQFFQ) dalam rentang waktu 1 bulan untuk mengetahui kebiasaan makan dan Food Record 2×24 jam digunakan untuk mengetahui tingkat kecukupan protein dan zat besi yang diambil pada hari yang mewakili hari sekolah dan hari libur, kemudian dihitung menggunakan software nutrisurvey. Pemilihan bahan makanan berdasarkan bahan makanan sumber protein, zat besi dan inhibitor zat besi yang paling sering dikonsumsi oleh responden. Data SQ-FFQ dikonversikan menjadi rata-rata frekuensi dan berat perhari untuk melihat kebiasaan makan. Data Food Record 2×24 dibandingkan dengan AKG (2019) untuk mendapatkan tingkat kecukupan gizi. ${ }^{21}$ Tingkat kecukupan zat gizi dibagi menjadi dua jenis yakni zat gizi makro dan mikro. Pengkategorian tingkat kecukupan zat gizi makro terbagi menjadi lima yaitu defisit tingkat berat $(<70 \%)$, defisit tingkat sedang (70\%-79\%), defisit tingkat ringan (80-89\%), normal $(90-119 \%)$, dan kelebihan $(\geq 120 \%) .{ }^{22}$ Pengkategorian tingkat kecukupan zat gizi mikro terbagi menjadi dua yaitu defisit $(<70 \%)$ dan normal $(\geq 70 \%) .{ }^{23}$

Data yang diperoleh kemudian dianalisis menggunakan analisis univariat dan bivariat. Analisis univariat dilakukan untuk mengidentifikasi usia subjek, tinggi badan, berat badan, z-score berdasarkan IMT/U, asupan protein, dan zat besi. Analisis bivariat dengan uji korelasi Spearman untuk mengukur hubungan antar variabel yakni asupan protein dan status gizi, asupan zat besi dan status gizi. Penelitian ini telah memperoleh izin dari Komisi Etik Penelitian Universitas Kristen Satya Wacana dengan No. 059/KOMISIETIK/EC/XI/2020 tanggal 3 November 2020.

\section{HASIL \\ Karakteristik Responden}

Responden pada penelitian ini berjumlah 88 siswi dengan karakteristik responden menurut usia dapat dilihat pada Tabel 4. Berdasarkan hasil penelitian ini, diketahui bahwa usia mayoritas responden di SMA Negeri 1 Kendal yaitu berusia 17 tahun sebesar $39,77 \%$.

Tabel 1. Distribusi Karakteristik Responden

\begin{tabular}{lcc}
\hline \multirow{2}{*}{ Karakteristik } & \multicolumn{2}{c}{ Total } \\
\cline { 2 - 3 } & $\mathrm{n}$ & $\%$ \\
\hline Usia & 32 & \\
15 & 12 & 36,36 \\
16 & 35 & 13,64 \\
17 & 9 & 39,77 \\
18 & 88 & 10,23 \\
\hline Total & & 100 \\
\hline
\end{tabular}

\section{Asupan Protein dan Zat Besi}

Berdasarkan hasil penelitian pada tingkat kecukupan protein (TKP) menggunakan data Food Record 2 × 24 jam menunjukkan bahwa terdapat 22 remaja putri memiliki TKP normal, 37 remaja putri memiliki TKP berlebih, dan 29 remaja putri mengalami defisit protein yang terbagi dalam kategori defisit ringan, sedang dan berat. Dapat dikatakan sebagian besar responden memiliki TKP berlebih. Terlihat bahwa rata-rata asupan protein responden adalah 78,19 gram/hari. Jumlah ini berada diatas kecukupan protein berdasarkan AKG bagi perempuan usia 13-18 tahun (2019) yaitu 65 gram/hari. ${ }^{21}$ Hal tersebut menunjukkan bahwa rata- rata tingkat kecukupan protein responden melebihi standar kecukupan gizi yang telah dianjurkan.

Hasil penelitian pada tingkat kecukupan zat besi menunjukkan bahwa remaja putri di SMA Negeri 1 Kendal sebanyak 48 orang $(54,55 \%)$ mengalami defisit. Hal tersebut dapat disebabkan oleh sebagian besar responden mengonsumsi makanan sumber zat besi kurang bervariasi dan sering mengonsumsi zat penghambat absorpsi zat besi seperti teh, coklat dan kopi. Hasil Food Record $2 \times 24$ jam mengenai asupan zat besi, didapatkan ratarata sebesar $13,10 \mathrm{mg} /$ hari. Nilai ini berada dibawah standar kecukupan zat besi berdasarkan AKG (2019) yaitu $15 \mathrm{mg} /$ hari. $^{21}$ 
Tabel 2. Distribusi Tingkat Kecukupan Asupan Protein dan Zat Besi (Fe)

\begin{tabular}{lcc}
\hline Tingkat Kecukupan Zat Gizi & n & \% \\
\hline Protein & & \\
Defisit Berat & 14 & 15,91 \\
Defisit Sedang & 7 & 7,95 \\
Defisit Ringan & 8 & 9,09 \\
Normal & 22 & 25,00 \\
Kelebihan & 37 & 42,05 \\
Zat Besi (Fe) & & \\
Defisit & 48 & 54,55 \\
Normal & 40 & 45,45 \\
\hline
\end{tabular}

Tabel 3. Distribusi Rerata Asupan Protein dan Fe Menggunakan Food Record 2 x 24 Jam

\begin{tabular}{lcc}
\hline \multirow{2}{*}{ Zat Gizi } & \multicolumn{2}{c}{ Asupan zat gizi } \\
& Rata-Rata \pm SD & minimal-maksimal \\
\hline Protein $(\mathrm{g})$ & $78,19 \pm 37,75$ & $16,85-237,62$ \\
$\mathrm{Fe}(\mathrm{mg})$ & $13,10 \pm 14,35$ & $1,52-85,80$ \\
\hline
\end{tabular}

Berdasarkan hasil penelitian pada kebiasaan makan remaja putri di SMA Negeri 1 Kendal yang diambil menggunakan SQ-FFQ selama 1 bulan terakhir, dapat diketahui bahwa cara pengolahan tersering pada bahan makanan sumber protein dan zat besi adalah digoreng, dibakar, dikecap, ditumis, dan direbus. Kelompok makanan sumber protein hewani yang paling banyak dikonsumsi oleh responden adalah telur ayam dengan rata-rata berat sebesar
41,44 gram per hari dan rata-rata frekuensi per hari yaitu 0,59 . Bahan makanan sumber protein nabati yang paling banyak dikonsumsi oleh responden adalah tempe dengan rata-rata berat sebesar 32,62 gram per hari dan rata-rata frekuensi per hari yaitu 0,49 . Responden terlihat lebih menyukai konsumsi makanan sumber protein nabati dibandingkan protein sumber hewani.

Tabel 4. Distribusi Frekuensi dan Berat Per Hari Konsumsi Bahan Makanan Sumber Protein, Zat Besi dan Inhibitor Zat Besi Menggunakan SQ-FFQ

\begin{tabular}{|c|c|c|c|}
\hline $\begin{array}{l}\text { Kelompok } \\
\text { Makanan }\end{array}$ & Bahan & $\begin{array}{l}\text { Rata-Rata Frekuensi } \\
\text { (per hari) }\end{array}$ & $\begin{array}{c}\text { Rata-Rata Berat Per } \\
\text { Hari (gram) }\end{array}$ \\
\hline \multicolumn{4}{|c|}{ Protein Hewani } \\
\hline Telur ayam & & 0,59 & 41,44 \\
\hline Daging ayam & & 0,44 & 23,10 \\
\hline Susu sapi & & 0,34 & 73,20 \\
\hline Udang segar & & 0,21 & 10,10 \\
\hline Keju & & 0,19 & 3,96 \\
\hline \multicolumn{4}{|c|}{ Protein Nabati } \\
\hline Tempe & & 0,49 & 32,62 \\
\hline Tahu & & 0,47 & 27,48 \\
\hline Kwaci & & 0,14 & 9,66 \\
\hline Kacang hijau & & 0,11 & 20,67 \\
\hline Jamur tiram & & 0,11 & 3,02 \\
\hline \multicolumn{4}{|l|}{ Zat Besi } \\
\hline Bayam & & 0,30 & 10,20 \\
\hline Daun seledri & & 0,23 & 3,55 \\
\hline Roti gandum & & 0,21 & 12,56 \\
\hline Kangkung & & 0,18 & 4,94 \\
\hline Brokoli & & 0,16 & 5,66 \\
\hline \multicolumn{4}{|c|}{ Inhibitor Zat Besi } \\
\hline Teh & & 0,50 & 94,82 \\
\hline Kopi & & 0,22 & 34,05 \\
\hline Coklat & & 0,15 & 13,75 \\
\hline
\end{tabular}


Kelompok bahan makanan sumber zat besi yang sering dikonsumsi oleh responden adalah bayam dengan rata-rata berat sebesar 10,20 gram per hari dan rata-rata frekuensi per hari yaitu 0,30. Hasil tersebut menunjukkan bahwa responden lebih sering mengonsumsi makanan sumber zat besi non heme. Bahan makanan penghambat sumber zat besi atau inhibitor yang sering dikonsumsi oleh responden adalah teh dengan rata-rata berat sebesar 94,82 gram per hari dan rata-rata frekuensi per hari yaitu 0,50 .

Tabel 5. Distribusi Status Gizi

\begin{tabular}{lcc}
\hline Status Gizi & $\mathbf{n}$ & $\mathbf{\%}$ \\
\hline Gizi kurang & 1 & 1,14 \\
Gizi baik & 74 & 84,09 \\
Gizi lebih/overweight & 10 & 11,36 \\
Obesitas & 3 & 3,41 \\
\hline Total & 88 & 100 \\
\hline
\end{tabular}

\section{Status Gizi}

Hasil IMT menurut z-score menunjukkan bahwa sebagian besar responden memiliki status gizi baik yaitu sebesar $84,09 \%$. Hal ini menunjukkan bahwa sebagian besar remaja putri di SMA Negeri 1 Kendal memiliki keseimbangan zat gizi antara pemasukan dengan pengeluaran energi dalam tubuh.

\section{Hubungan Asupan Protein, Zat Besi Dengan Status Gizi}

Berdasarkan hasil uji korelasi Spearman antara asupan protein dan status gizi $(\mathrm{p}=0,848$ dan $\mathrm{r}=0,021$ ) dapat diketahui bahwa tidak terdapat hubungan yang signifikan antara asupan protein dan status gizi. Hasil uji pada hubungan antara asupan zat besi dan status gizi $(p=0,685, r=0,044)$ menunjukkan bahwa tidak memiliki hubungan yang signifikan. Hal tersebut dapat dilihat dari hasil uji statistik hubungan antara asupan protein dengan status gizi yang menghasilkan $\mathrm{p}>0,05$.

Tabel 6. Korelasi Antar Variabel

\begin{tabular}{lcc}
\hline Variabel & p-value & $\begin{array}{c}\text { Koefisien Korelasi } \\
\text { (r) }\end{array}$ \\
\hline Asupan Protein dan Status Gizi & 0,848 & 0,021 \\
Asupan Zat Besi dan Status Gizi & 0,685 & 0,044 \\
\hline
\end{tabular}

\section{PEMBAHASAN}

\section{Karakteristik Responden}

Pengkategorian usia pada masa remaja dapat dibagi menjadi tiga fase yaitu fase remaja awal (usia 12-14 tahun), remaja pertengahan (usia 14-18 tahun), dan fase remaja akhir (usia 18-21 tahun). ${ }^{24}$ Sebaran usia responden pada penelitian ini berada pada fase remaja pertengahan yaitu usia 14-18 tahun. Masa remaja merupakan masa kritis dalam transisi diet dari pertengahan masa kanak-kanak hingga remaja ke dewasa. ${ }^{25}$ Remaja putri umumnya memiliki kebiasaan makan yang tidak sehat dan pola makan yang salah seperti tidak mengonsumsi makanan seimbang, makan tidak teratur, sering mengonsumsi makanan siap saji, serta diet rendah gizi dengan membatasi asupan makan yang mengabaikan sumber protein, lemak, karbohidrat, vitamin dan mineral. ${ }^{26}$ Kebiasaan makan tersebut dapat menyebabkan remaja tidak mampu memenuhi keanekaragaman zat gizi, sehingga akan berdampak pada kejadian kurangnya berbagai zat gizi yang dibutuhkan oleh tubuh. ${ }^{26}$

\section{Asupan Protein dan Zat Besi}

Protein memiliki peran penting sebagai zat pembangun dan pengatur, serta berfungsi sebagai komponen pada sel tubuh. ${ }^{27}$ Protein dapat diperoleh dari nabati dan hewani. Protein hewani memiliki kualitas lebih tinggi dibandingkan dengan protein nabati, karena mengandung komposisi asam amino esensial yang lengkap dan optimal untuk memenuhi kebutuhan manusia. ${ }^{28}$ Selain dari segi kualitas, jumlah atau kuantitas dari protein yang diasup juga penting untuk diperhatikan. Kebutuhan protein pada masa remaja meningkat secara signifikan, karena adanya peningkatan massa otot, kebutuhan eritrosit dan mioglobulin, serta perubahan hormonal. ${ }^{29}$

Pada awal masa remaja, kebutuhan protein remaja putri lebih tinggi dibandingkan laki-laki, karena remaja putri lebih cepat memasuki masa pertumbuhan terlebih dahulu. ${ }^{30}$ Seiring bertambahnya usia, remaja putri akan menambah berat badannya dengan cenderung menumpuk lemak sedangkan remaja laki-laki bertambah berat badan dengan meningkatkan massa otot dan rangka. ${ }^{31} \mathrm{Jadi}$, kebutuhan protein pada remaja putri lebih rendah dibandingkan dengan remaja laki-laki. 
Peningkatan asupan protein sangat efektif dalam penurunan berat badan dan pemeliharaan berat badan. $^{32}$ Protein akan memodulasi sinyal neuroendokrin terkait dengan rasa kenyang. ${ }^{33}$ Hal tersebut menyebabkan seseorang dapat memiliki rasa kenyang yang lebih lama dibandingkan dengan mengonsumsi karbohidrat dan lemak. ${ }^{34}$ Namun, peningkatan asupan protein secara berlebih dalam jangka waktu lama dapat meningkatkan risiko kardiometabolik pada remaja yang obesitas. ${ }^{35}$ Selain itu, dapat meningkatkan kerja pada hati, usus dan ginjal untuk mendetoksifikasi amonia dan hal tersebut seharusnya dihindari. ${ }^{36}$

Makanan yang tinggi protein hewani akan mengandung tinggi lemak, sehingga dapat menyebabkan terjadinya overweight maupun obesitas. ${ }^{37}$ Penelitian yang dilakukan oleh Lin et al (2015) menjelaskan bahwa terdapat korelasi positif antara asupan protein hewani dengan IMT dan persen lemak tubuh. ${ }^{37}$ Kandungan asam amino arginin, histidin dan leusin yang terdapat dalam protein hewani dapat meningkatkan sekresi insulin dan berkaitan dengan metabolisme lemak. ${ }^{38}$ Asupan protein yang berlebih juga dapat menyebabkan asam amino mengalami deaminiase. ${ }^{10}$ Hal tersebut menyebabkan nitrogen akan dikeluarkan dari tubuh dan sisa-sisa ikatan karbon akan diubah menjadi asetil $C O A$ yang dapat disintesis menjadi trigliserida melalui proses lipogenesis, kemudian disimpan dalam tubuh sehingga dapat menyebabkan kenaikan jaringan lemak yang akhirnya menyebabkan status gizi lebih. ${ }^{39}$

Remaja yang mengonsumsi protein nabati lebih tinggi dibandingkan dengan protein hewani menunjukkan persentase lemak tubuh dan BMI lebih rendah dibandingkan dengan remaja dengan asupan protein hewani yang lebih tinggi. ${ }^{40}$ Peningkatan asupan protein nabati pada remaja sebagai substitusi protein hewani untuk membantu mengontrol obesitas dan potensi manfaat positifnya untuk faktor kardiovaskular. ${ }^{37}$

Salah satu masalah kesehatan yang terkait dengan peningkatan asupan protein nabati yaitu adanya zat antigizi dalam bahan makanan nabati. Zat antigizi adalah bahan alami yang diproduksi oleh tumbuhan yang dapat merugikan bagi kesehatan tubuh seperti mengganggu sistem pencernaan, penyerapan atau pemanfaatan zat gizi dalam makanan dan mungkin memiliki efek merugikan lainnya. ${ }^{41}$ Namun, tidak semua zat antigizi dikaitkan dengan efek yang merugikan bagi kesehatan. Adapun zat antigizi yang memiliki efek menguntungkan, jika dikonsumsi pada tingkat atau kadar yang rendah. ${ }^{41}$

Remaja putri yang memiliki tingkat asupan protein yang rendah dan tidak memadai dalam jangka waktu yang lama dapat menyebabkan retardasi pertumbuhan linier dan pematangan seksual, penurunan massa otot, fungsi dan kekebalan organ, menghambat transportasi besi serta pengurangan massa tubuh bebas lemak. ${ }^{29}$ Selain itu, remaja putri juga akan berisiko mengalami KEK. $^{42}$ Pada penelitian Dictara et al (2020) menunjukkan bahwa asupan protein yang rendah dapat berisiko terjadinya KEK. ${ }^{43}$ Hal tersebut dapat terjadi karena peran protein dalam membangun struktur jaringan tubuh menjadi bagian akhir untuk menyuplai kebutuhan energi pada saat asupan karbohidrat dan lemak berkurang dan sebagai kompensasi apabila terjadi defisit energi. ${ }^{44}$

Kebutuhan yang tinggi akan zat besi pada remaja putri terutama disebabkan oleh kehilangan zat besi selama menstruasi dan proses pertumbuhan yang cepat, sehingga dapat menyebabkan volume darah, massa otot dan enzim-enzim meningkat. ${ }^{45}$ Kebutuhan absorpsi zat besi memuncak pada usia 14-15 tahun pada remaja putri. ${ }^{46}$ Pada penelitian yang dilakukan oleh Nelima et al (2015) menunjukkan bahwa remaja putri yang memiliki asupan zat besi rendah akan berisiko 9 kali lebih besar untuk menderita anemia dibandingkan remaja putri yang memiliki asupan zat besi yang cukup. ${ }^{47}$

Anemia memiliki konsekuensi serius pada masa remaja dengan retardasi pertumbuhan serta gangguan fisik dan kinerja kognitif. ${ }^{48}$ Zat besi berperan penting untuk fungsi neurotransmitter dalam kognisi, pembentukan $\mathrm{Hb}$ dan membantu proses metabolisme tubuh dengan membantu berbagai macam enzim dengan cara mengikat oksigen. ${ }^{48}$ Zat besi berikatan dengan protoporfirin untuk membentuk heme, selanjutnya heme akan berikatan dengan rantai polipeptida yang nantinya akan membentuk satu rantai $\mathrm{Hb}^{49}$ Masing-masing rantai akan berikatan menjadi empat rantai yang disebut dengan $\mathrm{Hb}$ lengkap.

Zat besi terdiri dari dua macam yaitu zat besi heme dan non heme. Menurut Gonete et al (2018), remaja putri dengan keragaman makanan yang tidak memadai akan mengalami anemia 2,1 kali lebih tinggi dibandingkan dengan remaja yang memiliki keragaman makanan yang baik. ${ }^{50}$ Hal tersebut menunjukkan bahwa mengonsumsi makanan yang beragam atau bervariasi dapat meningkatkan kecukupan mikronutrien dari makanan. Oleh karena itu, pola makan yang tidak beragam merupakan indikator tidak langsung dari asupan mikronutrien yang kurang baik, sehingga dapat meningkatkan kerentanan remaja terhadap anemia dan defisiensi mikronutrien lainnya. ${ }^{50}$

Asupan zat gizi yang tidak adekuat dalam jangka waktu yang lama dapat menyebabkan terjadinya anemia. ${ }^{51}$ Pemanfaatan zat besi oleh tubuh tergantung oleh ketersediaan hayati bagi tubuh. ${ }^{52}$ 
Penyerapan zat besi non heme sangat dipengaruhi oleh faktor makanan dan hal tersebut sifatnya dapat menghambat atau meningkatkan ketersediaan hayatinya. ${ }^{53}$ Zat besi heme memiliki ketersediaan hayati sebesar 15\%-35\% dan faktor makanannya memiliki sedikit pengaruh pada penyerapannya, sedangkan penyerapan zat besi non heme jauh lebih rendah yaitu sebesar 2\%-20\% dan sangat dipengaruhi oleh adanya komponen makanan lainnya. ${ }^{54}$ Masalah ketersediaan hayati ini, jika tidak dapat diatasi dengan baik, maka akan menyebabkan anemia defisiensi besi yang dapat memengaruhi fungsi tubuh lainnya. ${ }^{55}$

Makanan yang banyak mengandung zat besi dapat ditemukan pada daging merah (daging sapi), hati sapi, daging putih (daging ayam), produk susu dan telur, kacang-kacangan serta sayuran berwarna hijau. ${ }^{56}$ Zat besi yang tersedia secara hayati dan zat gizi mikro lainnya dapat memengaruhi risiko anemia. ${ }^{57}$ Remaja putri yang mengonsumsi buahbuahan dan sayuran berdaun hijau secara rutin juga diasosiasikan dapat mencegah terjadinya anemia. ${ }^{58}$ Hasil penelitian yang dilakukan oleh Suhada et al (2019) menunjukkan bahwa sayur bayam secara efektif dapat mempengaruhi perubahan kadar hemoglobin. ${ }^{59}$ Pentingnya mengonsumsi sayuran berdaun hijau tua berfungsi untuk menjaga $\mathrm{Hb}$ terutama pada remaja putri. ${ }^{60}$

Teh, kopi, dan coklat ditemukan mengandung zat inhibitor zat besi yaitu polifenol. ${ }^{61}$ Senyawa fenolik seperti asam tanat dan tanin yang terdapat pada teh akan menghambat penyerapan zat besi dalam lumen gastrointestinal, sehingga membatasi ketersediaan zat besi untuk penyerapan. ${ }^{62}$ Selama proses pencernaan, senyawa fenolik dari makanan atau minuman dilepaskan dan dapat terbentuk kompleks dengan Fe di lumen usus, sehingga tidak tersedia untuk penyerapan. ${ }^{63}$ Efek penghambatan polifenol pada serapan zat besi bergantung pada jumlah total polifenol yang diasup. ${ }^{64}$

Salah satu dampak dari kebiasaan mengonsumsi makanan tinggi sumber zat besi non heme adalah memiliki risiko yang lebih besar untuk terjadinya anemia. ${ }^{65}$ Hal tersebut dikarenakan adanya senyawa tertentu dari makanan nabati yang dapat menghambat penyerapan zat besi non heme. ${ }^{66}$ Oleh karena itu, remaja putri yang memiliki kebiasaan mengonsumsi zat besi non heme dianjurkan untuk meningkatkan vitamin $\mathrm{C}$ dan asupan asam organik lainnya untuk meningkatkan ketersediaan hayati zat besi dari makanan yang diasup. ${ }^{52}$

Pada hasil penelitian Fang et al (2015) menunjukkan bahwa asupan tinggi zat besi heme dapat meningkatkan risiko terjadinya diabetes, penyakit jantung koroner, kanker dan penyakit kardiovaskular. ${ }^{67}$ Makanan yang mengandung tinggi akan zat besi heme dapat menyebabkan oksidatif stres dan peroksidasi lipid. ${ }^{68} \mathrm{Hal}$ tersebut berkaitan erat dengan metabolisme nitrat atau nitrit dan pembentukan senyawa N-nitroso. ${ }^{69}$ Produksi senyawa $\mathrm{N}$-nitroso endogen dirangsang oleh zat besi heme, bukan oleh residu protein. ${ }^{70}$

\section{Status Gizi}

Status gizi dapat diartikan sebagai kondisi tubuh dalam hal-hal yang dipengaruhi oleh pola makan dan kemampuan tingkat zat gizi tersebut dalam menjaga integritas metabolisme normal. ${ }^{71}$ Status gizi baik atau optimal terjadi apabila tubuh memperoleh cukup zat-zat gizi yang digunakan secara efisien, sehingga memungkinkan pertumbuhan fisik, perkembangan otak, dan dapat menciptakan kesehatan pada tingkat setinggi mungkin. ${ }^{72}$ Status gizi lebih dan obesitas pada remaja dapat menyebabkan terjadinya gangguan kesehatan saat usia dewasa seperti gangguan fungsi pernapasan, risiko penyakit degeneratif, dan penyakit kardiovaskular. ${ }^{73}$ Status gizi kurang pada remaja putri akan meningkatkan risiko terhadap penyakit terutama penyakit infeksi, terhambatnya pertumbuhan dan perkembangan tubuh yang akan menentukan kondisi kesehatan di masa mendatang. ${ }^{74}$ Status gizi baik berperan penting dalam menentukan kesehatan pada remaja putri, sedangkan status gizi kurang dan lebih merupakan indikasi risiko gangguan kesehatan yang lebih besar bagi remaja putri. ${ }^{75}$ Untuk itu, masa remaja diidentifikasi sebagai kesempatan kedua untuk memperbaiki kekurangan dan ketidakcukupan gizi pada masa anak-anak.

\section{Hubungan Asupan Protein, Zat Besi Dengan Status Gizi}

Asupan protein dan zat besi memiliki peran penting pada kesehatan manusia. ${ }^{76}$ Asupan makan yang adekuat terkait dengan ketersediaan pangan dari segi kuantitas dan kualitas, kemampuan untuk mencerna, menyerap zat gizi. ${ }^{71}$ Faktor lainnya yang dapat memengaruhi status gizi seseorang diantaranya pendapatan keluarga, tingkat pendidikan, melewatkan makan dalam dua minggu terakhir, jumlah makan per hari, daya beli pangan, keragaman makanan, jumlah anggota keluarga dan pendapatan keluarga. ${ }^{77}$ Selain itu, faktor penentu sosiokultural seperti perubahan gaya hidup dan kebiasaan makan dapat memengaruhi status gizi ${ }^{78}$. Faktor yang cukup dominan memengaruhi keadaan status gizi adalah perilaku memilih dan memberikan makanan yang tidak tepat kepada anggota keluarga termasuk remaja putri. ${ }^{79}$ Berdasarkan penilitian Rahayu et al (2020) menunjukkan bahwa persentase sumbangan pengaruh pola makan, aktivitas fisik, body image, 
dan depresi terhadap status gizi remaja putri sebesar $6,9 \%{ }^{80}$

Hasil uji korelasi Spearman menunjukkan tidak adanya hubungan antara zat besi dengan status gizi. Hal tersebut menunjukkan bahwa asupan zat besi dibawah kebutuhan sehari-hari belum tentu dapat menyebabkan status gizi menjadi semakin buruk, karena asupan zat gizi lain masih dapat memenuhi kebutuhan tubuh dalam sehari-hari. ${ }^{79}$ Hasil penelitian ini sejalan dengan Setyawati et al (2012) menunjukkan bahwa asupan Fe tidak adanya hubungan yang signifikan dengan status gizi dengan $\mathrm{r}=0,089$ dan $\mathrm{p}=0,35 .{ }^{18}$ Hal ini dapat disebabkan karena perubahan status gizi dapat dipengaruhi oleh adanya perubahan berat badan, tinggi badan dan usia sehingga membutuhkan waktu yang lama. ${ }^{79}$

Hasil uji korelasi Spearman antara protein dengan status gizi menunjukkan bahwa tidak ada hubungan. Hasil penelitian ini sejalan dengan Irdiana (2017) pada siswi di SMA Negeri 3 Surabaya menunjukkan bahwa tidak ada hubungan antara asupan protein dengan status gizi. ${ }^{73}$ Status gizi tidak hanya dipengaruhi oleh asupan protein dan zat besi saja, melainkan aktivitas fisik, asupan karbohidrat, lemak dan vitamin dan mineral lainnya ikut berperan besar dalam memberikan status gizi ${ }^{81}$ Selain itu, asupan makanan dan kemampuan tubuh dalam menggunakan zat-zat makanan tersebut juga dapat memengaruhi status gizi. Penelitian ini menggunakan variabel asupan protein dan zat besi dikarenakan laju pertumbuhan terjadi dengan cepat pada masa remaja, sehingga protein memiliki peran penting dalam menunjang proses pertumbuhan dan asupan zat besi meningkat karena kebutuhan absorpsi zat besi memuncak pada masa remaja yang diakibatkan oleh adanya siklus menstruasi, proses pertumbuhan dan perkembangan. ${ }^{6,82}$ Remaja putri perlu upaya untuk menjaga asupan dan status gizinya agar selalu berada dalam kondisi yang optimal dengan berpedoman pada gizi seimbang, mengonsumsi makanan sesuai porsi masing-masing individu dan menghindari ketidakseimbangan antara zat gizi ${ }^{3}$.

\section{SIMPULAN}

Penelitian ini dapat disimpulkan bahwa tidak ada hubungan antara asupan protein dengan status gizi dan asupan zat besi dengan status gizi. Sebagian besar siswi memiliki status gizi baik, tingkat kecukupan protein berlebih, dan tingkat kecukupan zat besi defisit. Saran dari penelitian ini adalah remaja putri harus memerhatikan asupan makanan dengan memilih jenis makanan yang sehat, beragam, dan bergizi agar dapat memenuhi kebutuhan zat gizinya.

\section{UCAPAN TERIMA KASIH}

Ucapan terima kasih diberikan kepada SMAN 1 Kendal telah mengizinkan peneliti untuk melakukan pengambilan data di SMAN 1 Kendal, selain itu peneliti juga mengucapkan terima kasih kepada siswi kelas X dan XII di SMAN 1 Kendal yang telah bersedia menjadi responden serta ibu Dwi yang merupakan salah satu guru dan selaku bidang kurikulum di SMAN 1 Kendal telah banyak membantu dalam proses pengambilan data untuk penelitian ini.

\section{DAFTAR PUSTAKA}

1. Nurizky K, Teesa P, Apandi M. Assessment of nutritional status among elderly in ambulatory care setting. Althea Medical Journal. 2017; 4(2): 242-6. https://doi.org/10.15850/amj.v4n2.1087

2. Christian P, Smith ER. Adolescent undernutrition: global burden, physiology, and nutritional risks. Ann Nutr Metab. 2018; 72: 316-328. https://doi.org/10.1159/000488865

3. Rachmayani SA, Kuswari M, Melani V. Hubungan asupan zat gizi dan status gizi remaja putri di SMK Ciawi Bogor. Indonesian Journal of Human Nutrition. 2018; 5 (2): 125-130. https://doi.org/10.21776/ub.ijhn.2018.005.02.6

4. Kementerian Kesehatan Republik Indonesia (Kemenkes RI). Buku Saku Pemantauan Status Gizi (PSG) Tahun 2017. Jakarta: Direktorat Jenderal Kesehatan Masyarakat dan Gizi Masyarakat. 2018.

5. Al-Jawaldeh A, Taktouk M, Nasreddine L. Food consumption patterns and nutrient intakes of children and adolescents in the eastern mediterranean region: a call for policy action. Nutrients. $2020 ; \quad 12$ : 3345. https://doi.org/10.3390/nu12113345

6. Kahssay M, Mohamed L, Gebre A. Nutritional status of school going adolescent girls in Awash Town, Afar Region, Ethiopia. Journal of Environmental and Public Health. 2020; 2020: 9. https://doi.org/10.1155/2020/7367139

7. Omotayo AR, El-Ishaq A, Tijjani LM, Segun DI. Comparative analysis of protein content in selected meat samples (cow, rabbit, and chicken) obtained within damaturu metropolis. American Journal of Food Science and Health. 2016; 2(6): 151-155.

8. Mahan LK, Stump SE, Raymond JL, editors. Krauses's Food \& The Nutrition Care Process. 13th ed. USA-Elsevier Saunders. 2012. 415466.

9. Lonnie M, Hooker E, Brunstrom JM, Corfe BM, et al. Protein for life: review of optimal protein intake, sustainable dietary sources and the effect on appetite in ageing adults. Nutrients. 2018; 10: 360. https://doi.org/10.3390/nu10030360 
10. Febriani RT, Soesetidjo A, Tiyas FW. Consumption of fat, protein, and carbohydrate among adolescent with overweight/obesity. Journal of Maternal and Child Health. 2019; 4(2):

70-76. https://doi.org/10.26911/thejmch.2019.04.02.02

11. Arista AD, Widajanti L, Aruben R. Hubungan pengetahuan,sikap,tingkat konsumsi energi, protein, dan indeks massa tubuh/umur dengan kekurangan energi kronik pada remaja putri. Jurnal Kesehatan Masyarakat. 2017; 5(4): 585591.

12. Kementerian Kesehatan Republik Indonesia (Kemenkes RI). Hasil Utama Riset Kesehatan Dasar Tentang Prevalensi Kurang Energi Kronis dan Anemia Pada Tahun 2018. Jakarta: Badan Penelitian dan Pengembangan Kesehatan Kementerian RI. 2018.

13. Kemenetrian Kesehatan Republik Indonesia (Kemenkes RI). Riset Kesehatan Dasar 2018 : Laporan Provinsi Jawa Tengah 2018. Jakarta: Lembaga Penerbit Badan Penelitian dan Pengembangan Kesehatan (LPB). 2019.

14. Mesías M, Seiquer I, Navarro MP. Iron nutrition in adolescence. Crit Rev Food Sci Nutr. 2013; 53(11): 1226-37. https://doi.org/10.80/10408398.2011.564333

15. Umar F, Maallah MN. Analyze between consumption of vegetable and fruit with soft motor development of children In PAUD Nusa Indah Parepare. The Russian Union Catalog of Scientific Literature (Russian). 2013; 1(1): 1- 6. https://doi.org/10.1186/1479-5868-3-22

16. Coopmana MFM, Britoa A, López de Romana D, Pizarroa F, Olivares M. Body mass index, iron absorption and iron status in childbearing age women. Journal of Trace Elements in Medicine and Biology. 2015; 30: 215-219. https://doi.org/10.1016/j.jtemb.2014.03.008

17. Ernyasih, Riptifah S, Handari T. Hubungan antara aktivitas fisik dan konsumsi zat besi dengan status gizi pada remaja putri di SMP Yayasan Pendidikan Islam Bintaro Jakarta Selatan Tahun 2017. Jurnal Kedokteran dan Kesehatan. 2019; 15(1):56-62. https://doi.org/10.24853/jkk.15.1.56-62

18. Setyawati VAV, Faizah Z. Hubungan antara asupan protein, besi, dan seng dengan status gizi pada anak balita gizi buruk di wilayah kerja dinas kesehatan Kota Semarang. Jurnal Visikes. 2012; 11(1): 47-58. https://doi.org/10.33633/visikes.v11i1.663

19. ELMoslemany AG, ELBbandrawy AM, Elhosary EA, Gabr AA. Relation between body mass index and iron deficiency anemia in adolescent females. Curr. Sci. Int. 2019; 8(2): 403-410.

20. Kementerian Kesehatan Republik Indonesia (Kemenkes RI). Peraturan Peraturan Menteri Kesehatan Republik Indonesia Nomor 2 Tahun 2020 tentang Standar Antropometri Penilaian Status Gizi Anak. Keputusan Menteri Kesehatan Republik Indonesia. Jakarta: Kementerian Kesehatan Republik Indonesia. 2020.

21. Kementerian Kesehatan Republik Indonesia (Kemenkes RI). Peraturan Menteri Kesehatan Republik Indonesia Nomor 28 Tahun 2019 Tentang Angka Kecukupan Gizi (AKG) Yang Dianjurkan Untuk Masyarakat Indonesia. Jakarta: Kementerian Kesehatan Republik Indonesia. 2019.

22. Hardinsyah, Sulaeman A, Soekatri M, Riyadi H, et al. Ringkasan Angka Kecukupan Gizi (AKG) yang dianjurkan bagi orang Indonesia 2012. In: Rumusan Widyakarya Nasional Pangan dan Gizi (WNPG) X 2012. Bogor: Widyakarya Nasional Pangan dan Gizi (WNPG). 2012; p. 18.

23. Andriani VL, Indriani $Y$, Adawiyah R. Pola makan dan tingkat kecukupan gizi balita pada keluarga petani jagung. Jurnal Ilmu-ilmu Agraris. 2015; 3(4): 419-425. http://dx.doi.org/10.23960/jiia.v3i4.1092

24. Berge JM, Jin SW, Hannan P, Sztainer DN. Structural and interpersonal charactersics of family meals: association with adolescent body mass index and diettary pattern. Journal of The Academy of Nutrition and Dietetics. 2013; 113 (6):

816-822.

https://doi.org/10.1016/j.jand.2013.02.004

25. Winpenny EM, van Sluijs EMF, White M, Klepp K, Wold B, Lien N. Changes in diet through adolescence and early adulthood: longitudinal trajectories and association with key life transitions. Int J Behav Nutr Phy. 2018; 15(1): 86. https://doi.org/10.1186/s12966-0180719-8

26. Suryani D, Hafiani R, Junita R. Analisis pola makan dan anemia gizi besi pada remaja putri Kota Bengkulu. Jurnal Kesehatan Masyarakat Andalas. $\quad 2015 ; \quad 10(1)$ : 11-18. https://doi.org/10.24893/jkma.v10i1.157

27. Mercer AT, Riddle E, Barre L. Protein and amino acids for skeletal muscle health in aging. Adv Food Nutr Res. 2020; 91: 29-64. https://doi.org/10.1016/bs.afnr.2019.08.002

28. Marlene M, Machado S, Pimentel FB, Freitas $\mathrm{V}$, Alves RC, Oliveira MBPP. Amino acid profile and protein quality assessment of macroalgae produced in an integrated multitrophic aquaculture system. Foods. 2020; 9: 1382. https://doi.org/10.3390/foods9101382 
29. Ozdemir A. Macronutrients in adolescence. International Journal of Caring Sciences. 2016; 9(3): 1162

30. Mamidi RS, Rajkumar H, Radhakrishna KV, Babu JJ. Secular trends in heights and weights in boys and girls over 3 decades in rural India. Food Nutr Bull. 2016; 37(3): 425-438. https://doi.org/10.1177/0379572116647579

31. Carrasco-Luna J, Gombert M, Carrasco-García Á, Codoñer-Franch P. Adolescent feeding: nutritional risk factors. J Child Sci. 2018; 8: 99 105.

32. Hrolfsdottir L, Halldorsson TI, Rytter R, Bech $\mathrm{BH}$, Birgisdottir BE, Gunnarsdottir I, et al. Maternal macronutrient intake and offspring blood pressure 20 years later. J. Am. Heart Assoc. 2017; 6(4): 1-7.

33. Nguo K, Bonham M, Truby H, Barber E, Brown $\mathrm{J}$, Huggins CE. Effect of macronutrient composition on appetite hormone responses in adolescents with obesity. J. Nutrients. 2019; 11(340):

1-14. https://doi.org/10.3390/nu11020340

34. Kereliuk SM, Brawerman GM, Dolinsky VW. Maternal macronutrient consumption and the developmental origins of metabolic disease in the offspring. Int. J. Mol. Sci. 2017; 18(1451): 1-27. https://doi.org/10.3390/ijms18071451

35. Kim OY, Kim EM, Chung S. Impacts of Dietary Macronutrient pattern on adolescent body composition and metabolic risk: current and future health status: a narrative review. Nutrients. 2020; 12(3722): 1-16. https://doi.org/10.3390/nu12123722

36. Ko GJ, Obi Y, Tortoricci AR, Kalantar-Zadeh K. Dietary Protein intake and chronic kidney disease. Curr Opin Clin Nutr Metab Care. 2017; 20(1): $\quad$ 77-85.https://doi.org/ 10.1097/MCO.0000000000000342

37. Lin Y, Mouratidou T, Vereecken C, Kersting M, Bolca S, de Moraes ACF, et al. Dietary animal and plant protein intakes and their associations with obesity and cardio-metabolic indicators in european adolescents: the helena cross-sectional study. J.Nutrition. 2015; 14(10): 1-11. https://doi.org/10.1186/1475-2891-14-10

38. Bujnowski D, Xun P, Daviglus ML, Horn LV, $\mathrm{He}$ K, Stamler J. Longitudinal association between animal and vegetable protein intake and obesity among men in The United States: The Chicago Western Electric Study. American Dietetic Association. 2011; 111: 1150-1155. https://doi.org/10.1016/j.jada.2011.05.002

39. Rosati P, Triunfo S, Scambia G. Child Nutritional Status : A representative survey in a metropolitan school. journal of obesity, Hindawi
Publishing Corporation. 2013; 2013: 1-4. https://doi.org/10.1155/2013/395671

40. Hertzler SR, Lieblein-Boff JC, Weiler M, Allgeier C. Plant proteins: assessing their nutritional quality and effects on health and physical function. Nutrients. 2020; 12(3704): 127. https://doi.org/10.3390/nu12123704

41. Popova A, Mihaylova D. Antinutrients in plantbased foods: a review. J. Open Biotechnol. 2019; 13(1): 68-76. https://doi,org/10.2174/1874070701913010068

42. Subasinghe AK, Walker KZ, Evans RG, Srikanth V, Arabshahi S, Kartik K, et al. Association between farming and chronic energy deficiency in Rural South India. PLoS ONE. $\quad 2014 ; \quad 9(1): \quad 1-9$. https://doi.org/10.1371/journal.pone.0087423

43. Dictara AA, Angraini DI, Mayasari D, Karyus A. Hubungan asupan makan dengan kejadian kurang energi kronis (kek) pada ibu hamil di wilayah kerja Puskesmas Sukaraja Kota Bandar Lampung. Majority. 2020; 9(2): 1-6.

44. Ruaida N. Tingkat konsumsi energi dan protein dengan kejadian kurang energi kronis (KEK) pada siswa putri di SMA Negeri 1 Kairatu. Global Health Science. 2017; 2(4): 361-365. http://dx.doi.org/10.33846/ghs.v2i4.165

45. Engidaw MT, Wassie MM, Teferra AS. Anemia and associated factors among adolescent girls living in aw-barre refugee camp, somali regional state, Southeast Ethiopia. PLoS One. 2018; 13(10): https://doi.org/10.1371/journal.pone.0205381

46. Zeleke MB, Shaka MF, Anbesse AT, Tesfaye $\mathrm{SH}$. Anemia and its determinants among male and female adolescents in Southern Ethiopia: A Comparative Cross-Sectional Study. Hindawi Anemia. 2020; 2020: 1-10. https://doi.org/10.1155/2020/3906129

47. Nelima D. Prevalence and determinants of anaemia among adolescent girls in secondary schools in Yala Division Siaya District, Kenya. Journal of Food and Nutrition Science. 2015; 3(1), $1-9$. https://doi.org/10.13189/ujfns.2015.030101

48. Mistry SK, Jhohura FT, Khanam F, Akter F, Khan S, Yunus FMd, et al. An outline of anemia among adolescent girls in bangladesh: findings from a crosssectional study. BMC Hematology. 2017; $17(13)$ : $1-8$. https://doi.org/10.1186/s12878-017-0084-x

49. Wilkosz AB, Iciek M, Górny M, KowalczykPachel D. The role of hemoproteins: hemoglobin, myoglobin and neuroglobin in endogenous thiosulfate production processes. Int. J. Mol. Sci. 2017; 18 (6): 1-10. https://doi.org/ 10.3390/ijms18061315. 
50. Gonete KA, Tariku A, Wami SD, Derso T. Prevalence and associated factors of anemia among adolescent girls attending high schools in Dembia District, Northwest Ethiopia, 2017. Archives of Public Health. 2018; 76(79): 1-9. https://doi.org/10.1186/s13690-018-0324-y

51. Kahleova H, Pelikanova T. Vegetarian diets in the prevention and treatment of type 2 diabetes. J Am Coll Nutr. 2015; 34(5): 448-458. https://doi.org/10.1080/07315724.2014.976890

52. Skolmowska D, Głabska D. Analysis of heme and non-heme iron intake and iron dietary sources in adolescent menstruating females in a national polish sample. Nutrients. 2019; 11(15): 1-21. https://doi.org/10.3390/nu11051049

53. Coad J, Pedley K. Iron deficiency and iron deficiency anemia in women. Scandinavian Journal of Clinical \& Laboratory Investigation. 2014; 74 (Suppl 244): $82-89$. https://doi.org/10.3109/00365513.2014.936694

54. Abbaspour N, Hurrell R, Kelishadi R. Review On iron and its importance for human health. J. Res. Med. Sci. 2014; 19(2): 164-174.

55. Seriki SA, Adebayo OF, Odetola AO. Iron: from dietary sources to utilization in the body. Glob $\mathrm{J}$ Nano. $2017 ; \quad 3(3)$ : $1-7$. https://doi.org/10.19080/GJN.2017.03.555615

56. Zhu Z, Sudfeld CR, Cheng Y, Qi Q, Li S, Elhoumed M, et al. Anemia and associated factors among adolescent girls and boys at 10 14 years in rural Western China. BMC Public Health. 2021; 21(218): 1-14. https://doi.org/10.1186/s12889-021-10268-Z

57. Sun J, Zhang L, Cui J, Li S, Lu H, Zhang Y, Li $H$, Sun J, Baloch Z. Effect of dietary intervention treatment on children with iron deficiency anemia in China: A Meta-Analysis. Lipids Health Dis. 2018; 17(1): 1-6. https://doi.org/ 10.1186/s12944-018-0749-x

58. Ghatpande NS, Apte PP, Naik SS, Kulkarni PP. Fruit and vegetable consumption and their association with the indicators of iron and inflammation status among adolescent girls. J Am Coll Nutr. 2019; 38(3): 218-226. https://doi.org/ 10.1080/07315724.2018.1492470

59. Suhada RI, Fitriani A, Widiany FL. efektivitas sayur bayam terhadap perubahan kadar hemoglobin remaja putri di SMP 3 Kalasan, Sleman, Yogyakarta. Jurnal Pangan dan Gizi. $2019 . \quad 9(1)$ : 16-26. https://doi.org/10.26714/jpg.9.1.2019.16-26

60. Kamalaja T, Prashanthi M. Impact of change in dietary behaviors and iron supplementation for reduction of iron deficiency anemia in rural adolescent girls. International Journal of
Agricultural Science and Research. 2017; 7(4): 525-528. $\quad$ https://doi.org/ 10.13140/RG.2.2.19106.53443

61. Williamson G. The role of polyphenols in modern nutrition. Nutrition Bulletin. 2017; 42(3):

$226-235$.

https://doi.org/10.1111/nbu.12278

62. Milman NT. A review of nutrients and compounds, which promote or inhibit intestinal iron absorption: making a platform for dietary measures that can reduce iron uptake in patients with genetic haemochromatosis. Journal of Nutrition and Metabolism. 2020; 2020: 1-15. https://doi.org/10.1155/2020/7373498

63. Dasa F, Abera T. Factors affecting iron absorption and mitigation mechanisms: A Review. Int J Agric Sc Food Technol. 2018; 4(1): 24-30.

64. Yang J, Dwyer JT, Peterson JJ. Polyphenols in Foods. Nutrition Today. 2016; 51(6): 290-300. https://doi.org/ 10.1097/NT.0000000000000183

65. Haider LM, Schwingshack1 L, Hoffmann G, Ekmekcioglu C. The effect of vegetarian diets on iron status in adults: a systematic review and meta-analysis. Crit. Rev. Food Sci. Nutr. 2018; 58(8): 1359-1374. https://doi.org/ 10.1080/10408398.2016.1259210

66. Saunders AV, Craig WJ, Baines SK, Posen JS. Iron and vegetarian diets. Med J Aust. 2013; 199(4): 11-16. $\quad$ https://doi.org/ 10.5694/mja11.11494

67. Fang X, An P, Wang H, Wang X, Shen X, Li X, et al. Dietary intake of heme iron and risk of cardiovascular disease: a dose-response metaanalysis of prospective cohort studies. Nutr. Metab Cardiovasc Dis. 2015; 25(1): 24-35. https://doi.org/ 10.1016/j.numecd.2014.09.002

68. Guéraud F, Taché S, Steghens JP, Milkovic L, Borovic-Sunjic S, Zarkovic N, et al. Dietary polyunsaturated fatty acids and heme iron induce oxidative stress biomarkers and a cancer promoting environment in the colon of rats. Free Radic Biol Med. 2015; 83:192-200. https://doi.org/10.1016/j.freeradbiomed.2015.0 2.023.

69. Habermeyer M, Roth A, Guth S, Diel P, Engel $\mathrm{KH}$, Epe B, Fürst $\mathrm{P}$, et al. Nitrate and nitrite in the diet: how to assess their benefit and risk for human health. Mol Nutr Food Res. 2015; 59(1): 106-128.

https://doi.org/10.1002/mnfr.201400286.

70. Etemadi A, Sinha R, Ward MH, Graubard BI, Inoue-Choi M, Dawsey SM, et al. Mortality from different causes associated with meat, 
heme iron, nitrates, and nitrites in The NIHAARP Diet and Health Study: Population Based Cohort Study. BMJ. 2017; 357: 111. https://doi.org/10.1136/bmj.j1957

71. Begum A, Sharmin KN, Hossain MA, Yeasmin $\mathrm{N}$, Ahmed T. Nutritional status of adolescent girls in a rural area of Bangladesh: A Cross Sectional Study. Bangladesh J. Sci. Ind. Res. 2017; 52(3), 221-228. https://doi.org/10.3329/bjsir.v52i3.34158

72. Asmare B, Taddele M, Berihun S, Wagnew F. Nutritional status and correlation with academic performance among primary school children, Northwest Ethiopia. BMC Res Notes. 2018; 11(1): 1-6. https://doi.org/10.1186/s13104-0183909-1

73. Irdiana W, Nindya TS. Hubungan kebiasaan sarapan dan asupan zat gizi dengan status gizi siswi SMAN 3 Surabaya. Amerta Nutr. 2017; 1(3):

227-

235. http://dx.doi.org/10.20473/amnt.v1i3.201 7.227-235

74. Larega TSP. Pengaruh sarapan terhadap tingkat konsentrasi pada remaja. Artikel Review J Majority. 2015; 4(2): 115-121.

75. Branca F, Piwoz E, Schultink W, Sullivan LM. Nutrition and health in women, children, and adolescent girls. BMJ. 2015; 351: 27-31. https://doi.org/10.1136/bmj.h4173

76. Bhandari S, Sayami JT, Thapa P, Sayami M, Kandel BP, Banjara MR. Dietary intake patterns and nutritional status of women of reproductive age in Nepal: Findings From A Health Survey. Archives of Public Health. 2016; 74(2): 1-11. https://doi.org/10.1186/s13690-016-0114-3

77. Yasin MA, Tefera TB. Nutritional status and associated risk factors among adolescent girls in agarfa high school, Bale Zone, Oromia Region, South East Ethiopia. International Journal of Nutrition and Food Sciences. 2015; 4(4): 445452.

78. Kaur M, Kaur R, Walia P. Exploring gender disparity in nutritional status and dietary intake of adolescents in Uttarkashi. Indian Journal of Human Development. 2020; 14(1): 115-127. https://doi.org/10.1177/0973703020917502

79. Syaugi AM, Istianah I. Hubungan asupanzat besi $(\mathrm{Fe})$, riwayat MPASI dengan status gizi $\mathrm{BB} / \mathrm{U}$ pada balita usia 12-59 bulan. Binawan Student Journal(BSJ). 2019; 1(3): 1-5.

80. Rahayu TB, Fitriana. Analisis faktor-faktor yang mempengaruhi status gizi remaja putri. JVK. 2020; 6(1): $46-51$.

81. Siwi NP, Paskarini I. Hubungan asupan karbohidrat, lemak dan protein dengan status gizi (studi kasus pada pekerja wanita penyadap getah karet di perkebunan Kalijompo Jember). The Indonesian Journal of Public Health. 2018; 13(1): $1-12$. https://doi.org/10.20473/ijph.v13i1.2018.1-12

82. Widawati. Gambaran kebiasaan makan dan status gizi remaja di SMAN 1 Kampar Tahun 2017. Jurnal Gizi: Nutritions Journal. 2018; 2(2013): 146-159. 